\title{
Complete Protein Sequences of the Variable Regions of the Cloned Heavy and Light Chains of a Human Anti-Cytomegalovirus Antibody Reveal a Striking Similarity to Human Monoclonal Rheumatoid Factors of the Wa Idiotypic Family
}

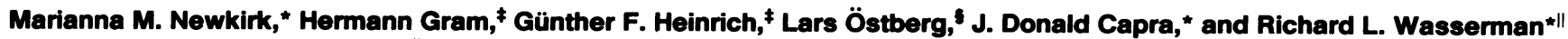 \\ Departments of *Microbiology and "Pediatrics, the University of Texas Health Sciences Center at Dallas, Dallas, Texas 75235; \\ ${ }^{\ddagger}$ Sandoz Ltd., Basel, Switzerland; and the ${ }^{\S}$ Sandoz Research Institute, East Hanover, New Jersey 07936
}

\begin{abstract}
The complete amino acid and nucleotide sequences of the variable regions of the heavy and light polypeptide chains of a human neutralizing IgGl anti-cytomegalovirus (CMV) antibody reveal a striking homology to IgM rheumatoid factors (RFs) of the Wa idiotypic family. The anti-CMV antibody and Wa RFs have in common $V_{K}$ IIIb, $J_{K} l$, and $V_{H}$ Ia gene segments but use different $D_{H}$ and $J_{H}$ gene segments. The anti-CMV antibody does not have $\mathrm{RF}$ activity and does not express the Wa idiotype. The Wa RFs do not have anti-CMV activity. A subset of Wa RFs, however, and the anti-CMV antibody do share several idiotypes on the $V_{H} I a$ and $V_{K}$ IIIb polypeptides. Since there are major differences in the antigen binding characteristics and some of the other expressed idiotypes, these data suggest that the $D$ and $J$ region amino acids are crucial to such specificities. Although the use of such highly homologous gene segments in different immune responses is well-documented in murine systems, these data represent the first such example in the human.
\end{abstract}

\section{Introduction}

Although there is extensive structural data on human immunoglobulin variable regions, most sequences are derived from immunoglobulins of unknown antibody specificity or autoantibodies. While this information has been crucial to elucidating the structure of human antibodies and has formed the basis of hypotheses relating to the generation of human antibody diversity, it is likely that much of the human immunoglobulin variable region repertoire is directed at specific exogenous antigens. The study of immunoglobulins with functional antibody activity is key to establishing the biological context of variable region sequence data and confirming the applicability of principles based on sequences of myeloma proteins and autoantibodies.

During the course of continued investigations on the structure of human antibodies, we examined an MAb

Dr. Newkirk's present address is Montreal General Hospital Research Institute, McGill University, Montreal, Quebec, H3G1A4, Canada. Dr. Wasserman's present address is Baylor University Medical Center, Department of Pediatrics, 3500 Gaston Avenue, Dallas, TX 75246. Address reprint requests to him.

Received for publication 31 July 1987 and in revised form 11 November 1987.

J. Clin. Invest.

(c) The American Society for Clinical Investigation, Inc.

$0021-9738 / 88 / 05 / 1511 / 08 \quad \$ 2.00$

Volume 81, May 1988, 1511-1518
(EVl-15) that neutralizes cytomegalovirus (CMV). ${ }^{1}$ The complete amino acid sequences of the variable regions of this antibody revealed a striking homology to human monoclonal rheumatoid factors (RFs) of the major idiotypic family. Specifically, the VK, JK, and VH gene segments of both the Wa RFs and EVl-15 are derived from the same or very closely related germ line gene segments. Consistent with their structural similarity, Wa RFs and EVl-15 share several serological determinants. The structural and serologic similarity of these molecules provides a possible link between the immune response to a ubiquitous virus and a common autoantibody.

The striking similarity of EVl-15 to a subpopulation of RFs raises interesting questions relating to the human variable region repertoire and the idiotype network theory of immunoregulation, as well as the association of viral infection and autoantibody production. While viral infections have been implicated in several forms of acute arthritis $(1,2)$, their role in the etiology and/or pathogenesis of RA remains unclear (3). EBV (4-8), rubella $(9,10)$, hepatitis B (1), vaccinia (11), and CMV $(12,13)$ have been associated with $R A$, although the role of viruses in the inflammatory process has resisted elucidation. Postulated mechanisms include $(a)$ cross-reactivity between viral antigens and host tissue, $(b)$ alteration of host tissue by virus rendering host tissue antigenic, and $(c)$ chronic infection and/or destruction of host tissue directly leading to inflammation (2). The circumstantial evidence implicating viruses includes rising titers of antiviral antibodies during the course of rheumatoid disease (7), isolation of live virus from rheumatoid joint tissue (12), and extensive epidemiologic analysis (3). Nonetheless, the issue has remained controversial.

A major feature of RA is the autoimmune diathesis present in most patients. Over $75 \%$ of adult patients with rheumatoid disease produce RF (14), an anti-gamma globulin whose serum titer has been shown to correlate with disease activity (15). More significant has been the direct demonstration that RFs may be produced in vitro by synovial B cells (16). The finding that RF was virtually the only immunoglobulin synthesized locally in the rheumatoid synovium refocused attention on RF and its possible primary or secondary role in the basic disease process.

Since the RFs produced in adult RA are polyclonal in nature, although of restricted heterogeneity (17), most structural and serologic studies on RFs have taken advantage of the syndrome of mixed cryoglobulinemia. Extensive studies of these human monoclonal RFs have defined groups of RFs

1. Abbreviations used in this paper: $\mathrm{CDR}$, complementarity determining regions; CMV, cytomegalovirus; D, diversity region; Fab, antibody binding fragment; Fc, crystallizable fragment; $\mathrm{H}$, heavy chain; IDDM, insulin-dependent diabetes mellitus; J, joining region; L, light chain; $R F$, rheumatoid factors; $V$, variable region. 
based on the expression of cross-reactive idiotypes $(18,19)$. The Wa idiotypic family, representing $\sim 60 \%$ of monoclonal RFs, has been found to be highly restricted in the use of light and heavy chain variable region gene segments (20-28). This is analogous to the restricted use of immunoglobulin variable region gene segments in murine antigen specific systems, many of which bear cross-reactive idiotypes. The relationship between these monoclonal RFs and the RFs present in RA was demonstrated by Pernis and his colleagues, who showed that the plasma cells of patients with RA contained idiotype-positive material (29). Some of the autoantibodies produced during the course of RA thus are structurally similar to the antibodies so extensively studied in mixed cryoglobulinemia (30). Since anti-idiotypic antibodies to RF have been described in patients with monoclonal RFs (31), they may play a role in the regulation of $R F$ production and thus may either initiate or perpetuate RF synthesis.

\section{Methods}

Preparation of monoclonal anti-CMV antibodies. The antibody EVl-15 was generated by fusing human splenic B lymphocytes with the SPAZ cell line (Östberg, L., E. Pursch, and M. Scriba, manuscript in preparation). This antibody was purified from tissue culture supernatants by affinity chromatography using Staphylococcal Protein A.

Preparation of monoclonal IgM RFs. These antibodies were purified from the plasma (a gift from R. Wistar, Naval Medical Research Institute, Bethesda, MD) of patients BOR, KAS, and RIV with mixed cryoglobulinemia as previously described (32).

Antigenic specificity. EVl-15, BOR, KAS, and RIV were tested for RF activity both by latex agglutination and ELISA. For the ELISA, plates were coated with $10 \mu \mathrm{g} / \mathrm{ml}$ crystallizable fragment $(\mathrm{Fc})$ (from human $\mathrm{IgGl}$ ) in carbonate-bicarbonate buffer, $\mathrm{pH} 9.6$, for $16 \mathrm{~h}$ at $4^{\circ} \mathrm{C}$. Incubations were performed with the IgM RFs at concentrations of 0.02-2.0 pM, with a monoclonal IgG RF (SFL) (33) at concentrations of 20-200 pM, and with EVl-15 at concentrations of 20-500 pM. The bound MAbs were detected with peroxidase-conjugated goat antihuman kappa antisera (Cappel Laboratories, Cochranville, PA). EVI-15, BOR, KAS, and RIV were tested for anti-CMV activity by neutralization assays and by ELISA (Östberg, L., E. Pursch, and M. Scriba, manuscript in preparation).

Sera from 20 patients with classical RA or insulin-dependent diabetes mellitus (IDDM) and 40 normal controls were tested for RF activity by ELISA as above. Sera were diluted 1:50 in PBS for initial screenings. Total RF, detected by the peroxidase-conjugated goat anti-human kappa antiserum and IgM RF, detected by peroxidaseconjugated goat anti-mu ( $\mathrm{Fc}$ specific) antiserum was measured.

Expressed Idiotype. BOR, KAS, RIV, EVI-15; sera from patients with RA and IDDM; and normal controls were analyzed by ELISA for reactivity to a goat antiserum that detected a private idiotype on EVl-15 (34). Briefly, plates coated with $10 \mu \mathrm{g} / \mathrm{ml}$ antiidiotypic antisera were incubated with $100 \mu \mathrm{l}$ of monoclonal RFs, $200 \mathrm{ng}$ EVl-15, or sera from patients or normal controls (diluted 1:100 in PBS). The bound antibodies were detected with peroxidase-conjugated goat anti-human kappa antiserum. An irrelevant, peroxidase-conjugated goat antimouse Ig antiserum (Cappel Laboratories) was used in parallel to control for antibodies reactive to goat immunoglobulin. The BOR, KAS, RIV, and EVI-15 MAbs were assayed for expression of the Wa idiotype and idiotopes found on human monoclonal RFs as previously described (22). Patient and normal sera (as above), the RFs, EVl-15, and other random myeloma proteins were analyzed for reactivity to the antibody binding fragment, $\left(\mathrm{F}\left[\mathrm{ab}^{\prime}\right]_{2}\right)$ of an absorbed rabbit serum raised to EVl-15 that was affinity purified from the RF BOR, which defines a new idiotype 1-15(B) by ELISA using the conditions as outlined for the analysis of the private EVl-15 idiotype.
Reactivity with antisera raised to the complementarity determining regions (CDR) of a $W a R F(S I E)$. The heavy and light chains of EVI-15 were separated on SDS-PAGE and immunoblotted with antisera to the peptides PSL2, PSL3, and PSH3 as previously described (35-37).

Preparation of fragments for protein sequencing. Fab fragments of EVl-15 were made by digesting the IgGl with papain (HG papain, Worthington Biochemicals, Malvern, PA) according the method of Poljak et al. (38). The Fab and Fc were separated by affinity chromatography using Protein A-Sepharose (Pierce Chemical Co., Rockford, IL).

The purified Fab fragments were chemically cleaved with an equal weight of cyanogen bromide. The cyanogen bromide digest was reduced and alkylated as previously described (39). Peptides were separated initially by reverse phase chromatography using a $\mathrm{C} 4$ column (Vydac, Hesperia, CA) and a linear gradient of $0.1 \%$ trifluoroacetic acid in water to $0.1 \%$ trifluoroacetic acid in $50 \%$ acetonitrile and $15 \%$ isopropanol for $90 \mathrm{~min}$ at a flow rate of $1.0 \mathrm{ml} / \mathrm{min}$. The initial peaks were further resolved using reverse phase chromatography on a $\mathrm{C} 18$ column (Aquapore RP300; Brownlee Labs, Santa Clara, CA) developed with the gradient described above. Peptides that were $\geq 35$ amino acids long were further digested with trypsin with or without prior citraconylation (39). The resultant peptides were separated by reverse phase chromatography as above.

Initial studies showed that the amino terminus of the heavy chain resisted Edman degradation. Therefore, pyroglutamic amino peptidase was used according to the method of Podell and Abraham (40) to cleave the cyclized amino-terminal amino acid.

Protein sequencing. Peptides were subjected to automated Edman degradation using either the gas phase sequencer (model 470; Applied Biosystems Inc., Foster City, CA) with the model 120, on-line HPLC phenylthiohydantoin amino acid identification system, or a spinning cup sequencer (model 890M; Beckman Instruments, Inc., Fullerton, CA). In the latter case, the phenylthiohydantoin amino acids were identified using a NovaPac column in an HPLC system (model 840; Waters Associates, Milford, MA). Compositional analyses of peptides were done by amino acid analysis using an amino acid analyzer (model 6300; Beckman Instruments, Inc.).

Cloning the EVl-15 rearranged heavy and light chain genes. The DNA fragments encoding the EVI-15 light and heavy chain variable regions were identified by Southern filter hybridization. Bam HI-digested DNA from human placenta, EVI-15, and the SPAZ cell lines were probed with a human $\mathrm{C}_{\mathrm{K}}$-specific $2.7-\mathrm{kb}$ Eco RI fragment (41) and a 7.5-kb Hind III fragment encoding the human gamma 1 exons (42). Methods for the cloning procedures were essentially as described by Heinrich et al. (43). Briefly, DNA fragments of the appropriate size were selected from Bam HI-digested EVI-15 DNA on a agarose-gel and cloned into bacteriophage lambda EMBL4. Approximately $4 \times 10^{5}$ phage plaques were screened with the $C_{K}$ probe and $5 \times 10^{4}$ plaques were screened with the $C$ probe. Three phage clones for each heavy and light chain were found to hybridize specifically with the probes. Subfragments encoding the rearranged heavy chain variable region gene, identified by crosshybridization with human $J_{H}$ specific oligonucleotide probes (synthesized on an Applied Biosystems 380 A DNA synthesizer), were cloned into bacteriophage M13mp18 for nucleotide sequencing.

Heavy and light chain recombination experiments. The heavy and light chains of EVl-15, BOR, and RIV (the latter a structurally and idiotypically unrelated RF) were separated and recombined following the procedure of Jeske et al. (44). Briefly, the immunoglobulin of interest was reduced and alkylated in the presence of $5 \mathrm{M}$ guanidine and $50 \mathrm{mM}$ Tris- $\mathrm{HCl}, \mathrm{pH}$ 8.0. Heavy and light chains were separated by gel filtration in guanidine, using a $\mathbf{S} 200$ column $(2.5 \times 100 \mathrm{~cm})$ (Pharmacia Fine Chemicals, Piscataway, NJ). Fractions were analyzed by SDS-PAGE for heavy or light chain and then pooled. Heavy and light chains were mixed to form homologous or heterologous molecules and dialyzed slowly into Tris-buffered saline $(50 \mathrm{mM}$ Tris- $\mathrm{HCl}$ and $0.15 \mathrm{M} \mathrm{NaCl}, \mathrm{pH}$ 7.4). Recombined molecules were separated 
from free light and heavy chains by precipitation with $40 \%$ ammonium sulfate. The precipitated molecules migrated at $75-90 \mathrm{kD}$ (depending on the heavy chain in question) in nonreducing SDS-PAGE and as a light chain $(24 \mathrm{kD})$ and a heavy chain $(50-65 \mathrm{kD})$ in reducing conditions. Homologous and heterologous chain recombinants were analyzed for biological activity and expression of idiotype as above.

\section{Results}

The light chain variable region sequence of anti-CMV antibody $E V l-15$. Southern filter hybridization using the kappa specific probe demonstrated hybridization with a $10.5-$ and $11-\mathrm{kb}$ fragment in EVl-15 and placental DNA digested with Bam HI, respectively, indicating a rearranged $C_{K}$ gene (data not shown). The probe did not crosshybridize with any SPAZ DNA fragment. This result confirms previous karyotypic analysis of the SPAZ cell line, which showed that it had lost all but two human chromosomes. After library screening, the 3.4-kb Eco $\mathrm{RV}$ fragment of the light chain variable region was cloned into the Sma I site of M13mp18. The nucleotide sequence and the derived amino acid sequence of the cloned EVl-15 light chain is presented in Fig. 1. The EVl-15 $\mathrm{V}_{\mathrm{K}}$ gene segment is joined in frame to the human $J_{K} 1$ gene segment (45). The leader peptide is interrupted by a 186 -bp intron. The amino acid sequence determined by classical protein sequencing techniques was determined independently and was found to be identical to that deduced from the nucleotide sequence. The variable region exon can be classified as a human kappa light chain of the $\mathrm{V}_{\mathrm{K}}$ IIIb subgroup (46).

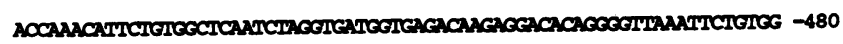

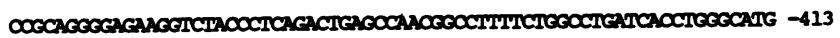

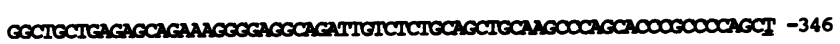

\section{$10-\operatorname{mon}$}

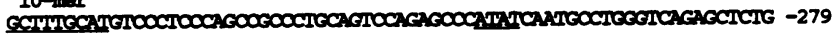

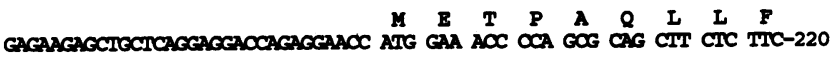

L I I I $\quad$ W I $\quad$ P $A$

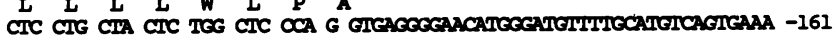

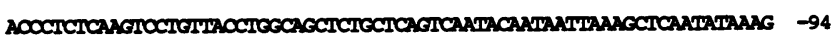

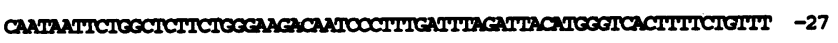

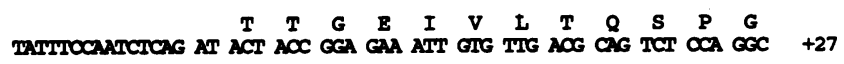

$\begin{array}{llllllllllllllllll} & T & I & S & L & S & P & G & E & R & A & T & I & S & C & R & A & S\end{array}$

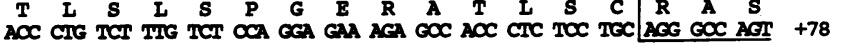

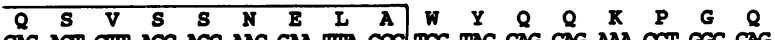
CAG ACT GIT ACC AEC AAC CAA TIVA COC TEG TAC CAG CAG AAA COT GEC CAG +129

\begin{tabular}{lllllll|llllllllll}
$A$ & $P$ & $R$ & $I$ & $L$ & $I$ & $S$ & $G$ & $A$ & $S$ & $R$ & $R$ & $A$ & $T$ & $G$ & $I$ & $P$
\end{tabular}

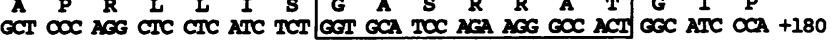

$\begin{array}{lllllllllllllllll}D & R & F & S & G & S & G & S & G & T & D & F & T & I & T & I & S\end{array}$

GAC AGG TIC AET GGG AGT GEG TCT GEG ACA GAC TIC ACT CTC AOC ATC AGC +231

\begin{tabular}{llllllllllll|lllll}
$R$ & $L$ & $E$ & $P$ & $E$ & $D$ & $F$ & $A$ & $M$ & $Y$ & $Y$ & $C$ & $Q$ & $Q$ & $Y$ & $G$ & $S$
\end{tabular}

ACA CIG GAG OCT GAN GAT TIT GOG ATG TAT TAC TGT CAG CAG TAT GCA AGT +282

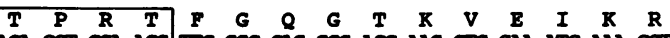

ACA CIT CA AOE TIC GEC CAG GEG AOC AAG GIG GAA ATC AAA OOICAGT +33I

Figure 1. The nucleotide sequence of the light chain Eco RV fragment of EVl-15. Amino acids are designated by the single-letter code. The CDRs are boxed.
The heavy chain variable region sequence of anti-CMV antibody EVl-15. Southern filter hybridization of EVl-15 and placental Bam HI-digested DNA using the $C$ probe showed four and five crosshybridizable fragments, respectively (data not shown). After library screening, the 2.2-kb Bam HI-Hind III fragment was cloned into the Sma I site of M13mp18 for nucleotide sequence analysis. The heavy chain clone contained only the part of the variable region encoding the mature variable domain (exon 2) because of a Bam HI site within the leader intron. The amino acid sequence determined by classical protein sequencing techniques was identical to the sequence deduced from the DNA sequence in the coding region of this rearranged gene (Fig. 2). This variable region can be classified as a heavy chain belonging to the $\mathrm{V}_{\mathrm{H}}$ Ia subgroup (22). When the DNA sequence of EVl-15 was compared with another $V_{H} I a$ subfamily member, the 783 rearranged gene (J. V. Ravetch and S. Korsmeyer, personal communication), $89 \%$ nucleotide identity was detected in the coding region and $87 \%$ identity in the entire cloned gene ( $463 \mathrm{bp}$ ).

The EVl-15 D segment does not match any published D segment (47) and is one of the longest $D$ regions described to date. The junctional V-D amino acid, asparagine (GAT), was probably formed by the addition of the $T$ (from either the $D$ gene element or added by terminal transferase) to the GA that has been seen in the germ line of an unrearranged, related $V_{H} I$ gene (48).

The $\mathrm{J}_{\mathrm{H}}$ gene segment used in EVl-15 can be classified as a $\mathrm{J}_{\mathrm{H}} 6(49)$. The nucleotide and amino acid sequence differences from the germ line $J_{\mathrm{H}} 6$ can be explained by single base substitutions. Alternately, EVl-15 uses a $J_{H} 6$ segment that is one codon shorter than the germ line $J$ segment, similar to that seen in the heavy chain variable region exon cloned from a human plasma cell line, ARH-77 (50). The 783 rearranged gene, which also uses a $J_{H} 6$ gene element, is three nucleotides longer $\left(5^{\prime}\right)$ and is more closely related to the genomic nucleotide sequence of $\mathrm{J}_{\mathrm{H}} 6$.

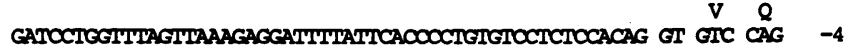
$\begin{array}{llllllllllllllll}S & Q & V & Q & I & V & Q & S & G & A & E & V & K & K & P & G\end{array}$ TOC CAG GIG CAG TIG GIG CAG TCT GGG GCT GAG GIG AAG AAG OCT GEG +45 $\begin{array}{lllllllllllllll}S & S & V & K & V & S & C & K & A & S & G & G & T & F & S \\ S\end{array}$ TOC TOG GIG AAG GIC TOC TGC AAG GCT TCT GCA GGC AOC TTC AGC AAGT +93

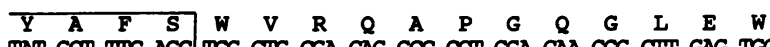
TAT GCT TIC AGC TEG GIG OCA CAG GOC OCT GGA CAA GEG CIT GAG TEG +141 $\begin{array}{lllllllllllllll}\mathbf{G} & \mathbf{G} & \text { I } & \text { I } & \text { P } & \text { F } & \text { L } & \text { G } & \text { T } & \text { T } & \text { H } & \text { Y } & \text { A } & \mathbf{Q} & \text { K }\end{array}$ ATG GCA GGC ATC ATC CCT TIC TIMA GEG ACA ACA CAC TAC GCA CAG AAA +189

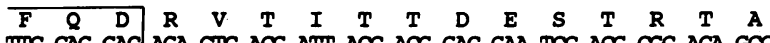
TIC CAG GAC ACA GIC AOG ATT AOC AOG GAC GAA TOC AOG OOC ACA GOC +237

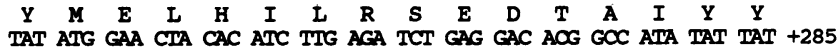

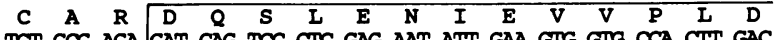
TGT GOG AGA CAT CAG TOC CIC GAG AAT ATT GAA GIG GIG OCA CIT GAC +333 \begin{tabular}{lllllllllllllllllllllll}
\hline$P$ & $N$ & $Y$ & $F$ & $Y$ & $D$ & $G$ & $M$ & $D$ & $V$ & W & $G$ & $Q$ & $G$ & $T$ & $T$
\end{tabular} OCI AAT TAC TIC TAC GAC GGT ATG GAC GIC TGG GGC CAA GGG AOC AOG +381

$\begin{array}{lllll}V & T & \mathrm{~S} & \mathrm{~S}\end{array}$

GIC AOC GIC TOC TCAGGT +399

Figure 2. The nucleotide sequence of the heavy chain Bam HI-Hind III fragment of EV1-15. Amino acids are designated by the single-letter code. The CDRs are boxed. 
Amino acid sequence similarity of EVl-15 and human RFs of the Wa idiotypic group. The comparison of the amino acid sequences of the variable region light and heavy chains of the anti-CMV antibody, EVl-15, and two members of the Wa family of RFs (22) are presented in Fig. 3 and 4. The EVl-15 light chain variable region (positions 1-96) has 91 and $92 \%$ amino acid identity to KAS and BOR, respectively. BOR and KAS have $93 \%$ amino acid identity. It is likely that all three variable regions (positions 1-96) are derived from the same KIIIb gene segment. Like BOR, EVl-15 uses a $J_{K} 1$ gene segment. The junctional V-J amino acid in EVl-15 is an arginine, which is the amino acid most frequently (33\%) seen at this position in the $12 \mathrm{Wa}$ RF light chains sequenced to date.

When the heavy chain variable regions are compared (Fig. 4), EVl-15 has 85 and $86 \%$ amino acid identity to KAS and BOR, respectively (KAS and BOR are $87 \%$ identical). All three variable regions probably were derived from either the same $\mathrm{V}_{\mathrm{H}}$ Ia gene or closely related genes of this subsubfamily. In contrast, the molecules differ markedly in their $\mathrm{D}$ and $\mathrm{J}$ regions (Fig. 5). EVl-15 has a 14 or 15 amino acid long D region and uses a $J_{H} 6$ gene element, whereas BOR and KAS have a 9 amino acid long $\mathrm{D}$ region and a $\mathrm{J}_{\mathrm{H}} 4$ gene segment (22).

Antigenic specificity of EVl-15 and Wa RFs. The human RFs were found to have no detectable anti-CMV activity, either by ELISA or by virus neutralization. The anti-CMV antibody, EVl-15, did not have RF activity by ELISA, even when assayed at higher protein concentrations and for longer incubation periods than are usually necessary to demonstrate the binding of a human IgG RF (SFL) to Fc. Hybrid molecules formed by the recombination of the BOR heavy chain and either the BOR or EVl-15 light chain but not the RIV light chain ( $\mathrm{V}_{\mathbf{K}}$ IIIa) were found to have detectable RF activity. No molecule formed by the recombination of the EVl-15 heavy chain and any light chain bound Fc. No hybrid molecule of any combination was found to neutralize CMV.

Idiotypic analysis of EVl-15 and Wa RFs. The analysis of the expression of the idiotypes associated with both $\mathrm{Wa}$ and related idiotopes and EVI-15 is presented in Table I. The EVl-15 molecule, as well as BOR and KAS, bear the idiotype 1-15B (which was not found on 20 other random myeloma proteins, or on SIE or WOL, two other Wa idiotypic RFs; data

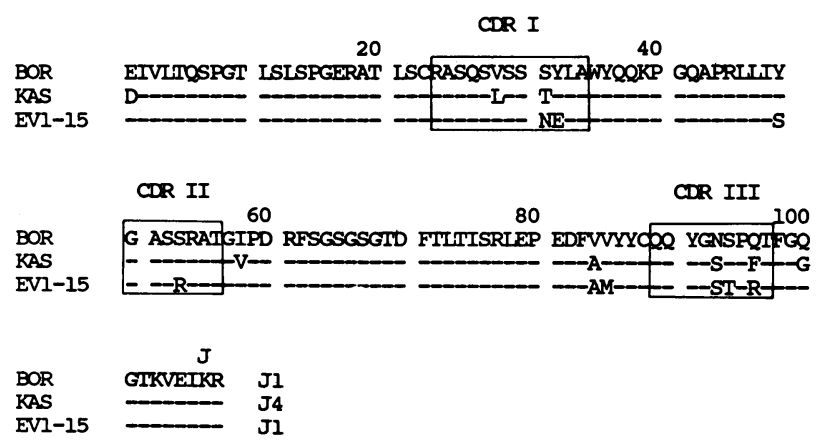

Figure 3. A comparison of the complete amino acid sequences of the light chain variable regions of two Wa idiotypic family RFs, BOR and KAS, and the anti-CMV antibody, EVI-15. Amino acids are given in the single-letter code, numbered according to Kabat (51). Identical amino acids are represented by dashes, changes in amino acids are indicated. Boxed areas delineate the CDRs I-III. BOR and KAS sequences from reference 22 .
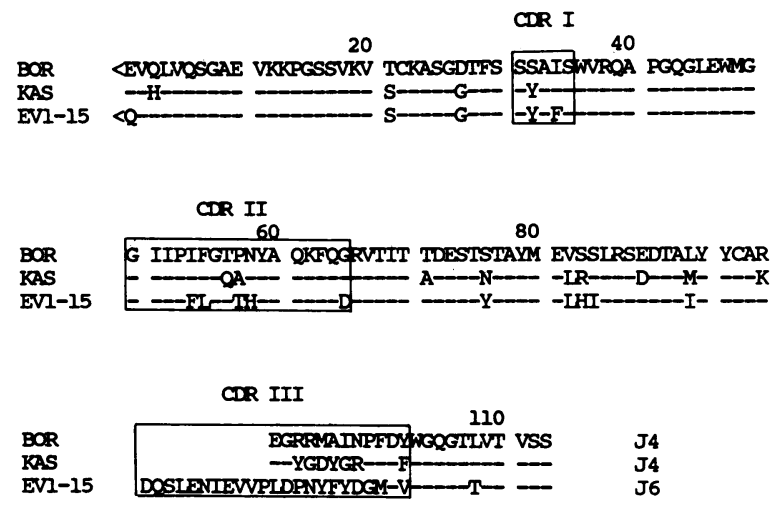

Figure 4. A comparison of the complete amino acid sequences of the heavy chain variable regions of two Wa idiotypic family RFs, BOR and KAS, and the anti-CMV antibody, EVl-15. Amino acids are designated by the single-letter code, numbered according to Kabat (51). Identical amino acids are represented by dashes, changes in amino acids are indicated. Boxed areas delineate the CDRs I-III. BOR and KAS sequences from reference 22.

not shown), but the EVl-15 molecule did not react with the polyclonal anti-Wa sera. The epitope recognized by MAb 17-109 has been reported to recognize a conformational determinant, dependent on intact light chain CDRs from RFs (52). The MAbs G6 and G8 appear to recognize an epitope on a subset of Wa RFs $(22,53,54)$. EVl-15 was not recognized by the MAbs 17-109, G8, or G6. EVl-15 was recognized by the MAbs B12 and C7, both of which recognize epitopes on the KIIIb light chain (54). The reactivity of the MAbs to EV1-15, however, was less than their reactivity with BOR and KAS.

Antisera raised to peptides with the amino acid sequence of the CDRs and in some cases neighboring framework amino acids of another Wa RF (SIE), were used to probe the EV1-15 molecule by Western blot analysis. EVl-15 reacted as well as the SIE protein with anti-PSL2 and anti-PSL3 sera (second and third light chain CDRs) (Table I); however, the anti-PSH3 sera (which recognizes the third CDR of BOR and SIE heavy chain) was nonreactive with the EVl-15 molecule.

Hybrid molecules formed by the recombination of heavy and light chains of EVl-15, BOR, and RIV were analyzed for the expression of idiotype as demonstrated in Table II. Successful heavy and light chain recombinations were evident from (a) the migration of a moiety at 75-90 kD (SDS-PAGE analysis) and ( $b$ ) the detection of biological activity (ability to bind $\mathrm{Fc}$ ) and the expression of idiotypes by the recombined homologous molecules. No such reactivities could be detected in the free heavy or light chain pools. Although no idiotype could be detected on the free heavy chain, it appeared that the three idiotypes were more associated with the heavy chain than the light chain. The $\mathrm{V}_{\mathrm{K}}$ IIIb light chains of EVl-15 and BOR

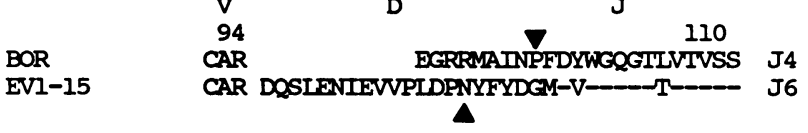

Figure 5. The amino acid sequences of the heavy chain $\mathrm{D}$ and $\mathrm{J}$ regions of one representative Wa RF, BOR, and the anti-CMV antibody, EVl-15. The D-J junctional amino acid is indicated. 
Table I. Reactivity of Antiidiotypic Sera/Antibodies and Anti-peptide Antisera to EVI-15 and Members of the Wa Idiotypic Family of Rheumatoid Factors, BOR and $K A S$ and RIV, a non-Wa RF

\begin{tabular}{|c|c|c|c|c|}
\hline \multirow{2}{*}{$\begin{array}{c}\text { Antisera/MAb } \\
\text { idiotype }\end{array}$} & \multicolumn{4}{|c|}{ Human monoclonal Igs } \\
\hline & EV1-15 & BOR & KAS & RIV \\
\hline Wa & $-*$ & ++ & ++ & - \\
\hline EV1-15 (private) & ++ & - & - & - \\
\hline $1-15(B)$ & ++ & +++ & +++ & - \\
\hline \multicolumn{5}{|c|}{ Light chain determinants } \\
\hline Anti-PSL2 & $++^{\ddagger}$ & ++ & + & - \\
\hline Anti-PSL3 & ++ & + & ++ & - \\
\hline B12 & $+^{*}$ & +++ & +++ & - \\
\hline C7 & ++ & +++ & +++ & - \\
\hline $17-109$ & - & ++ & ++ & - \\
\hline G8 & - & ++ & - & - \\
\hline \multicolumn{5}{|c|}{ Heavy chain determinants } \\
\hline Anti-PSH3 & - & ++ & - & - \\
\hline G8 & - & ++ & - & - \\
\hline G6 & - & ++ & ++ & - \\
\hline
\end{tabular}

* ELISA results:,$-<0.05 ;+, 0.05-0.5 ;++, 0.5-1.0 ;+++,>1.0$.

₹ Results with anti-peptide (PSL2, PSL3, and PSH3) antisera based on autoradiographic detections on Western blots.

appeared to be interchangeable and could form hybrids with either heavy chain with subsequent expression of the idiotype associated with the parent molecule from which the heavy chain was isolated. The 1-15(B) idiotype could not be detected on intact Wa RFs SIE and WOL, which have the $\mathrm{V}_{\mathbf{K}}$ IIIb light chain but not the $\mathrm{V}_{\mathrm{H}} \mathrm{Ia}$ heavy chain, lending further support to the hypothesis that for this idiotype to be expressed, a specific heavy chain variable region must be present. The $V_{K}$ IIIa light

Table II. Expression of Idiotype by Hybrid Immunoglobulins from Homologous and Heterologous Recombinations of Heavy and Light Polypeptide Chains from the Anti-CMV Antibody EVI-15, and Two RFs, BOR* and RIV

\begin{tabular}{lllccc}
\hline \multicolumn{2}{c}{ Recombination } & & \multicolumn{3}{c}{ Expression of idiotype } \\
\cline { 1 - 3 } Heavy chain & Light chain & & Wa & EV1-15 & $1-15$ (B) \\
\hline EV1-15 & None & & - & - & - \\
EV1-15 & EV1-15 & + & ++ & ++ \\
EV1-15 & BOR & & - & ++ & + \\
EV1-15 & RIV & & ND & + & - \\
BOR & None & & - & ND & - \\
BOR & BOR & + & - & ++ \\
BOR & EV1-15 & ++ & - & +++ \\
BOR & RIV & & - & ND & - \\
RIV & RIV & - & ND & - \\
RIV & BOR & - & ND & - \\
& & & & & \\
\hline
\end{tabular}

,$+ 0.1-0.2 ;++, 0.2-0.3 ;+++, 0.3-0.4$ OD units, when assayed at $20 \mu \mathrm{g} / \mathrm{ml}$.

* Wa idiotypic family.

${ }^{\ddagger}$ By structural analysis similar to the Po idiotypic family (33). chain of RIV (another RF, structurally similar to the Po family [33]) appeared not to form hybrids capable of expressing either the Wa or the shared $1-15$ (B) idiotypes with either BOR or EVl-15 heavy chains. Weak expression of the private EVl-15 idiotype was detected on the hybrid formed from the EVl-15 heavy chain and the RIV light chain.

Rheumatoid factor activity and expression of EVl-15 Idiotypy in patients with RA or IDDM or normal individuals. $\mathrm{Pa}$ tients with RA (90\%), some normal individuals (5\%), and patients with IDDM (5\%) were found to have detectable IgM RFs (Table III). The 1-15(B) idiotype was detected in $20 \%$ of normal controls and $50 \%$ of patients with RA and IDDM. Antibodies expressing the private EVl-15 idiotype were not detected in the sera from 20 patients with RA, 20 patients with IDDM, or 40 normal controls (data not shown). Only EVl-15 was positive for the private idiotype in the assay when controlled with the irrelevant goat anti-mouse sera. In contrast, it appeared that $62 \%$ of RA patients, $45 \%$ of IDDM patients, and $15 \%$ of normal controls had antibodies that were reactive with several goat sera (this reactivity could be either RFs or antiFab antibodies).

\section{Discussion}

These data document a striking serologic and primary structural similarity between a human anti-CMV antibody and the RFs of the Wa cross-reactive idiotype group. Three of the five gene elements, representing $>95 \%$ of the primary structures of these two sets of antibodies, are derived from the same or very similar germ line gene segments. While an important reservation concerning these data is that only a single human antiCMV antibody has been sequenced, the data have important implications for our understanding of the use of the human immunoglobulin gene repertoire, and provide information concerning the importance of $\mathrm{D}$ and $\mathrm{J}$ segments in the $\mathrm{Wa}$ cross-reactive idiotype. Additionally, the results suggest a potentially important interrelationship between viral infections and RA and provide a possible framework to investigate the network concept of immunoregulation.

The light chain variable region of $\mathrm{EVl}-15$ is closely related to the light chains of IgMWa idiotypic RFs. Chain recombination experiments document that the light chains of the antiCMV antibody and RFs are interchangeable without affecting RF binding specificity. Both the Wa- and EV1-15-associated idiotypes could be restored to isolated heavy chains (Table II) by heterologous light chains. No antivirus activity could be

Table III. Detection of Rheumatoid Factor and the Expression of the 1-15(B) Idiotype in Patients with RA, IDDM, and in Normal Controls

\begin{tabular}{|c|c|c|c|c|}
\hline & & $\mathrm{RF}^{*}$ & IgM RF & $\begin{array}{l}1-15 \text { (B) } \\
\text { idiotype }\end{array}$ \\
\hline Patients/normal controls & No. & Positive (\%) & Positive (\%) & Positive (\%) \\
\hline Normal & 40 & $5(13)$ & $2(5)$ & $8(20)$ \\
\hline RA & 20 & $18(90)$ & $18(90)$ & $10(50)$ \\
\hline IDDM & 20 & $10(50)$ & $2(5)$ & $10(50)$ \\
\hline
\end{tabular}

* Detected with antihuman kappa. 
detected in any of the recombined hybrid molecules. It is likely that the proper refolding of the very large heavy chain CDRIII of EVl-15 is critical for such activity. There is a striking similarity between the nucleotide sequence of EVl-15 light chain and the published sequence of the related germ line KIIIa genes, 305 and 321 (55), the latter of which may be a KIIIb. The EVl-15 light chain $V$ region is 120 nucleotides longer than 305 ( $5^{\prime}$ of coding). Within the untranslated region, including the leader sequences (440 bp), the two sequences (305 and EVl-15) are $97 \%$ identical. There is $95 \%$ identity in the coding region. The 321 gene, which is thought to be more closely related to the RF KIIIb, has $96 \%$ nucleotide identity (164 bp) with EV1-15. The KIIIb light chain has been shown to be primarily associated with the IgM isotype in normal human sera (56).

There has been considerable controversy concerning the significance of the highly restricted use of KIIIb light chains, primarily in autoantibodies $(21,24,54,55)$. Since EVl-15 exhibits potent anti-CMV activity, it is apparent that the restriction of the KIIIb light chain to autoantibodies is not exclusive. It appears that, based on the strong reactivity of the anti-PSL2 serum to the EVl-15 light chain, this antiserum probably recognizes a stretch of amino acids between positions 54 and 61, which is predominantly framework III. Clearly, this anti-peptide serum is able to recognize antibodies that do not have RF activity, confirming the observations of Agnello et al. (57). EVl-15, however, is the first antibody not selected for autoreactivity that reacts with this antiserum. The CDRIII of the light chain of EVl-15 is indistinguishable from an RF CDRIII. The antipeptide antiserum that is reactive with this region is equally reactive with SIE RF and EVl-15 molecules.

EVl-15 uses the $J_{K} l$ gene element, which is also most commonly used by the Wa idiotypic RFs $(21,22)$. The junctional amino acid arginine, between the V-J in EVl-15, is also the most commonly seen amino acid in this position. There thus is a striking similarity between the $V_{K}$ and $J_{K}$ gene segments used by EVl-15 and the major (Wa) class of human RFs.

The heavy chain variable region of $\mathrm{EVl}-15$ is highly related to the heavy chain variable region of $W a$ family $R F s$. The EVl-15 $V_{H}$ region is $85 \%$ identical to the Wa RFs of the $V_{H} I a$ subgroup and by definition EVl-15 is a member of this $V_{H}$ subgroup. The amino acid substitutions in CDRI and II of EVl-15 are limited in number and conservative and as such are unlikely to account for the differences in antigen specificity. The $\mathrm{D}$ and $\mathrm{J}$ regions (CDRIII), however, are very different between the anti-CMV antibody and the RFs (Fig. 5) and most likely account for the difference in the antigen binding characteristics, as well as the observed differences in the expression of idiotype. This difference lends further support to the importance of the D-J4 region $(22,25,58)$ of the RFs, both for expression of the Wa idiotype and for antigen binding. Until other related anti-CMV antibodies with the same specificity are described, no firm conclusions about the importance of parts of the variable regions to anti-CMV activity can be made. When compared with the RFs, however, it is clear that the D-J6 region is important for both the anti-CMV binding activity and the expression of the idiotype associated with EVl-15.

Most of the structural and serological information about RFs has been derived from the study of monoclonal IgM RFs isolated from patients with mixed cryoglobulinemia. The rele- vance of this information to the polyclonal RFs has been established by several studies that have identified antibodies similar to the monoclonal RFs, based on their expressed idiotype (Wa) in individuals with RA $(26-30,52,54)$.

The serologic and structural similarity of the major idiotypic family of RF antibodies and the anti-CMV antibody, EVl-15, may provide a link between the immune response to a common virus and $R A$. Several possibilities are suggested: (a) that CMV causes RA in a genetically susceptible host. (Several studies have shown a clear association of RA with HLA, in particular DR4, [59, 60] and it is likely that other genes may also be involved. In these individuals, the immune response to CMV that produces a viral neutralizing anti-CMV antibody may also induce autoantibodies.); (b) that CMV does not cause RA, but when a patient with RA is exposed to CMV, the immune response also produces autoantibodies; and $(c)$ that the structural homology that exists between RFs and EVl-15 is coincidental and only reflects the limited human germ line antibody repertoire.

In addressing the first possibility, it is clear that not all patients with RA have been exposed to CMV. Although this virus is ubiquitous and several studies have shown that up to $75 \%$ of patients with RA have antibodies to CMV, this may not be significantly different from normal controls $(13,61)$. There has, however, been one report of the isolation of cytomegalovirus from synovial cells of a patient with RA (12).

The second possibility, that a CMV infection in a patient with established RA results not only in anti-viral antibodies, but also in RFs, suggesting a possible malfunctioning network system, is also feasible. The fact that RFs have been detected in persons with infections such as bacterial endocarditis, syphilis, leprosy, tuberculosis, and AIDS $(62,63)$ suggests that some individuals with an activated immune system may respond to such an infectious agent and also produce autoantibodies.

The third possibility, that there is a limited immunoglobulin repertoire in man, is unlikely. There is no evidence that the ability to produce diverse antibody specificities is limited relative to other mammals, in which the estimated repertoire is $10^{7}$ to $10^{8}$ antibodies. It is possible, however, that the number of human germ line variable segment genes commonly used is limited and that antibody diversity is generated primarily by selection among many $\mathrm{D}$ segment genes, as well as by junctional and $\mathrm{N}$-segment mechanisms operating on $\mathrm{V}$-D-J recombination. The similarity of EVl-15 to Wa RFs thus may indicate that although $\mathrm{V}$ segment genes are the major components of variable regions, they may not be the primary determinants of precise binding specificity. If this explanation is correct, the serendipitous findings described herein support the notion that different immune responses may use the same gene segments. The data we report do not directly address the possible role of viral infections in the pathogenesis of autoimmune diatheses.

The striking similarity between the anti-CMV antibody and RF autoantibodies is not without precedent. In a mouse MAb system, two immunoglobulins differing by a single amino acid have been described. The parent antibody has antibacterial (specifically phosphorylcholine) activity, whereas the antibody differing by one amino acid no longer binds phosphorylcholine, but instead binds DNA (64). It is clear that the EVl-15 antibody and the Wa idiotypic family of RFs are more distantly related. Another parallel may exist in the production of a specific idiotypic family of anti-DNA antibodies 
after pulmonary tuberculosis or Klebsiella pneumoniae infections (65-67). Nonetheless, the striking serologic and structural similarity of these distinct antibodies may provide a crucial link between an antiviral response and an autoimmune disease.

\section{Acknowledgments}

We thank J. Eichman, N. Manitzas, E. Anderson, and C. Tschopp for their technical assistance, and $M$. Wright for her assistance in the preparation of the manuscript. Dr. U. Hurtenbach kindly provided the EVl-15 cells for the cloning experiments. Dr. R. Mageed expertly analyzed the Wa-related idiotope expression. Analysis of the reactivity to antipeptide sera was kindly done by Dr. P. P. Chen. The sera from patients and normal controls were donated by Dr. H. Jasin and Dr. M. Hoover.

This work was supported in part by grants from the National Institutes of Health (AI-12127, GM-31689), the Robert A. Welch Foundation (I-1026), and the North Texas Chapter of the Arthritis Foundation.

\section{References}

1. Wilkes, R. M., J. P. Simsarian, H. E. Hopps, H. Roth, J. L. Decker, R. G. Aptekar, and H. M. Meyer, Jr. 1973. Virologic studies on rheumatoid arthritis. Arthritis Rheum. 16:446-454.

2. Smith, L. H., Jr., and R. M. Wilkes. 1978. Arthritis caused by viruses. Calif. Med. 119:38-44.

3. Pasquali, J.-L., S. Fong, C. Tsoukas, J. H. Vaughan, and D. A. Carson. 1980. Inheritance of immunoglobulin $M$ rheumatoid-factor idiotypes. J. Clin. Invest. 66:863-866.

4. Capra, J. D., R. J. Winchester, and H. G. Kunkel. 1969. Coldreactive rheumatoid factors in infectious mononucleosis and other diseases. Arthritis Rheum. 12:67-73.

5. Alspaugh, M. A., F. C. Jensen, H. Rabin, and E. M. Tan. 1978. Lymphocytes transformed by the Epstein-Barr virus. Induction of nuclear antigen reactive with antibody in rheumatoid arthritis. J. Exp. Med. 147:1018-1027.

6. Silverman, S. L., and H. R. Schumacher. 1981. Antibodies to Epstein-Barr viral antigens in early rheumatoid arthritis. Arthritis Rheum. 24:1465-1468.

7. Alspaugh, M. A., D. Rosenstock, D. J. J. Biundo, and R. C. Gupta. 1983. Correlation of antibody to rheumatoid arthritis associated nuclear antigen and immune complexes to disease activity in patients with rheumatoid arthritis. Clin. Exp. Immunol. 51:278-284.

8. Billings, P. B., S. O. Hoch, P. J. White, D. A. Carson, and J. H. Vaughan. 1983. Antibodies to the Epstein-Barr virus nuclear antigen and to rheumatoid arthritis nuclear antigen identify the same polypeptide. Proc. Natl. Acad. Sci. USA. 80:7104-7108.

9. Kacaki, J. N., P. C. Balduzzi, and J. H. Vaughan. 1970. A study of Rubella haemagglutination inhibition antibodies in rheumatoid arthritis. Clin. Exp. Immunol. 6:885-889.

10. Ogra, P. L., Y. Chiba, S. S. Ogra, J. L. Dzierba, and J. K. Herd. 1975. Rubella-virus infection in juvenile rheumatoid arthritis. Lancet. i:1157-1161.

11. Brooks, P., M. Readett, and S. Kirov. 1978. Rheumatoid arthritis and generalized Vaccinia. JAMA (J. Amer. Med. Assoc.) 239:747748.

12. Hamerman, D., I. Gresser, and C. Smith. 1982. Isolation of cytomegalovirus from synovial cells of a patient with rheumatoid arthritis. J. Rheumatol. 9:658-664.

13. Venables, P. J. W., M. G. R. Ross, P. J. Charles, R. D. Melsom, P. D. Griffiths, and R. N. Maini. 1985. A seroepidemiological study of cytomegalovirus and Epstein-Barr virus in rheumatoid arthritis and sicca syndrome. Ann. Rheum. Dis. 44:742-746.

14. Fye, K. H., H. M. Mountsopoulos, and N. Talal. 1978. Immunogenetics. In Basic and Clinical Immunology. 2nd ed. H. H. Fuden- berg, D. P. Stites, J. L. Caldwell, and J. V. Wells, editors. Lange Medical Publications, Los Altos, CA. 422.

15. Withrington, R. H., I. Teitsson, $H$. Valdimarsson, and $M . H$. Seifert. 1984. Prospective study of early rheumatoid arthritis. II. Association of rheumatoid factor isotypes with fluctuations in disease activity. Ann. Rheum. Dis. 43:679-685.

16. Panush, R. S., A. K. Bittner, M. Sullivan, P. Katz, and S. Longley. 1985. IgM rheumatoid factor elaboration by blood, bone marrow, and synovial mononuclear cells in patients with rheumatoid arthritis. Clin. Immunol. Immunopathol. 34:387-391.

17. Persselin, J. E., J. S. Louie, and R. H. Stevens. 1984. Clonally restricted anti-IgG antibodies in rheumatoid arthritis. Arthritis Rheum. 27:1378-1386.

18. Kunkel, H. G., M. Mannik, and R. C. Williams. 1963. Individual antigenic specificity of isolated antibodies. Science (Wash. DC). 140:1218-1219.

19. Kunkel, H. G., V. Agnello, F. G. Joslin, R. J. Winchester, and J. D. Capra. 1973. Cross-idiotypic specificity among monoclonal IgM proteins with anti- $\gamma$-globulin activity. J. Exp. Med. 137:331-342.

20. Kunkel, H. G., R. J. Winchester, F. G. Joslin, and J. D. Capra. 1974. Similarities in the light chains of anti- $\gamma$-globulins showing crossidiotypic specificities. J. Exp. Med. 139:128-136.

21. Goni, F., P. P. Chen, B. Pons-Estel, D. A. Carson, and B. Frangione. 1985. Sequence similarities and cross-idiotypic specificity of $\mathbf{L}$ chains among human monoclonal IgMk with anti- $\boldsymbol{\gamma}$-globulin activity. J. Immunol. 135:4073-4079.

22. Newkirk, M. M., R. A. Mageed, R. Jefferis, P. P. Chen, and J. D. Capra. 1987. The complete amino acid sequences of the variable regions of two human IgM rheumatoid factors, BOR and KAS of the Wa idiotypic family reveal a restricted usage of heavy and light chain variable and joining region gene segments. J. Exp. Med. 166:550-564.

23. Andrews, D. W., and J. D. Capra. 1981. Amino acid sequence of the variable regions of heavy chains from two idiotypically crossreactive human IgM anti- $\gamma$-globulins of the Wa group. Biochemistry. 20:5822-5830.

24. Ledford, D. K., F. Goni, M. Pizzolato, E. C. Franklin, A. Solomon, and B. Frangione. 1983. Preferential association of KIIIb light chains with monoclonal human IgMK autoantibodies. J. Immunol. 131:1322-1325.

25. Agnello, V., and J. L. Barnes. 1986. Human rheumatoid factor cross idiotypes. I. WA and BLA are heat-labile conformational antigens requiring both heavy and light chains. J. Exp. Med. 164:18091814.

26. Pasquali, J.-L., A. Urlacher, and D. Storck. 1983. A highly conserved determinant on human rheumatoid factor idiotypes defined by a mouse monoclonal antibody. Eur. J. Immunol. 13:197-201.

27. Posnett, D. N., R. Wisniewolski, B. Pernis, and H. G. Kunkel. 1986. Dissection of the human antigammaglobulin idiotype system with monoclonal antibodies. Scand. J. Immunol. 23:169-181.

28. Agnello, V., A. Arbetter, G. Ibanez de Kasep, R. Powell, E. M. Tan, and F. Joslin. 1980. Evidence for a subset of rheumatoid factors that cross-react with DNA-histone and have a distinct cross-idiotype. J. Exp. Med. 151:1514-1527.

29. Bonaguro, U. R., H. G. Kunkel, and B. Pernis. 1982. Cellular localization of rheumatoid factor idiotypes. J. Clin. Invest. 69:13561365.

30. Forre, O., J. H. Dobloug, T. E. Michaelsen, and J. B. Natvig. 1979. Evidence of similar idiotype determinants on different rheumatoid factor populations. Scand. J. Immunol. 9:281-289.

31. Geltner, D., E. C. Franklin, and B. Frangione. 1980. Antiidiotypic activity in the IgM fractions of mixed cryoglobulins. J. Immunol. 125:1530-1535.

32. Newkirk, M. M., A. Edmundson, R. Wistar Jr., D. G. Klapper, and J. D. Capra. 1987. A new protocol to digest human IgM with papain that results in homogeneous Fab preparations that can be routinely crystallized. Hybridoma. 6:453-460.

33. Newkirk, M. M., and J. D. Capra. 1987. Restricted usage of 
immunoglobulin variable region genes in human autoantibodies. In The Immunoglobulin Gene. T. Honjo, T. Rabbits, and F. W. Alt, editors. Academic Press Inc., London. In press.

34. Erhlich, P. H., K. E. Harfeldt, J. C. Justice, Z. A. Moustafa, and L. Östberg. 1987. Rhesus monkey responses to multiple injections of human monoclonal antibodies. Hybridoma. 6:151-160.

35. Chen, P. P., R. A. Houghten, S. Fong, G. H. Rhodes, T. A. Gilberston, J. H. Vaughan, R. A. Lerner, and D. A. Carson. 1984. Antihypervariable region antibody induced by a defined peptide: an approach for studying the structural correlates of idiotypes. Proc. Natl. Acad. Sci. USA. 81:1784-1788.

36. Chen, P. P., S. Fong, D. Normansell, R. A. Houghten, J. G. Karras, J. H. Vaughan, and D. A. Carson. 1984. Delineation of a cross-reactive idiotype of human autoantibodies with antibody against a synthetic peptide. J. Exp. Med. 159:1502-1511.

37. Goldfien, R. D., P. P. Chen, S. Fong, and D. A. Carson. 1985. Synthetic peptides corresponding to third hypervariable region of human monoclonal IgM rheumatoid factor heavy chains define an immunodominant idiotype. J. Exp. Med. 162:756-761.

38. Poljak, R. J. 1985. Crystallization of immunoglobulins and their fragments for x-ray diffraction studies. Methods Enzymol. 116:190-200.

39. Newkirk, M., P. P. Chen, D. Carson, D. Posnett, and J. D. Capra. 1986. Amino acid sequence of a light chain variable region of a human rheumatoid factor of the Wa idiotypic group, in part predicted by its reactivity with antipeptide antibodies. Mol. Immunol. 23:239244.

40. Podell, D. N., and G. N. Abraham. 1978. A technique for the removal of pyroglutamic acid from the amino terminus of proteins using calf liver pyroglutamate amino peptidase. Biochem. Biophys. Res. Commun. 81:176-185.

41. Hieter, P. A., E. E. Max, J. G. Seidman, J. V. Maizel, and P. Leder. 1980. Cloned human and mouse kappa immunoglobulin constant and $\mathrm{J}$ region genes conserve homology in functional segments. Cell. 22:197-207.

42. Takahashi, N., S. Ueda, U. Shintaro, M. Obata, T. Nikaido, S. Nakai, and T. Honjo. 1982. Structure of human immunoglobulin gamma genes: implication for evolution of a gene family. Cell. 29:671-679.

43. Heinrich, G., A. Traunecker, and S. Tonegawa. 1984. Somatic mutation creates diversity in the major group of mouse immunoglobulin kappa light chains. J. Exp. Med. 159:417-435.

44. Jeske, D. J., J. Jarvis, C. Milstein, and J. D. Capra. 1984. Junctional diversity is essential to antibody activity. J. Immunol. 133:1090-1092.

45. Hieter, P. A., J. V. Maizel, Jr., and P. Leder. 1982. Evolution of human immunoglobulin $\mathrm{K} J$ region genes. J. Biol. Chem. 257:15161522.

46. Solomon, A., and C. L. McLaughlin. 1969. Bence Jones proteins and light chains of immunoglobulins. II. Immunochemical differentiation and classification of Kappa-chains. J. Exp. Med. 130:1295-1311.

47. Siebenlist, U., J. V. Ravetch, S. Korsmeyer, T. Waldmann, and P. Leder. 1981. Human immunoglobulin D segments encoded in tandem multigenic families. Nature (Lond.). 294:631-635.

48. Rechavi, G., D. Ram, L. Glazer, R. Zakut, and D. Givol. 1983. Evolutionary aspects of immunoglobulin heavy chain variable region $\left(\mathrm{V}_{\mathrm{H}}\right)$ gene subgroups. Proc. Natl. Acad. Sci. USA. 80:855-859.

49. Ravetch, J. V., U. Siebenlist, S. Korsmeyer, T. Waldmann, and P. Leder. 1981. Structure of the human immunoglobulin u locus: characterization of embryonic and rearranged $\mathrm{J}$ and $\mathrm{D}$ genes. Cell. 27:583-591.

50. Kudo, A., T. Ishihara, Y. Nishimura, and T. Watanabe. 1985. A cloned human immunoglobulin heavy chain gene with a novel direct-repeat sequence in 5' flanking region. Gene (Amst.). 33:181-189.
51. Kabat, E. A., T. T. Wu, H. Bilofsky, M. Reid-Miller, and $H$. Perry. 1983. Sequences of proteins of immunological interest. National Institutes of Health, Bethesda, MD. 1-323.

52. Carson, D. A., and S. Fong. 1983. A common idiotope on human rheumatoid factors identified by a hybridoma antibody. Mol. Immunol. 20:1081-1087.

53. Mageed, R. A., M. Dearlove, D. M. Goodall, and R. Jefferis. 1986. Immunogenic and antigenic epitopes of immunoglobulins. XVII. Monoclonal antibodies reactive with common and restricted idiotopes to the heavy chain of human rheumatoid factors. Rheumatol. Int. 6:179-183.

54. Mageed, R. A., M. R. Walker, and R. Jefferis. 1986. Restricted light chain subgroup expression on human rheumatoid factor paraproteins determined by monoclonal antibodies. Immunology. 59:473478.

55. Chen, P. P., K. Albrandt, N. K. Orida, V. Radoux, E. Y. Chen, R. Schrantz, F.-T. Liu, and D. A. Carson. 1986. Genetic basis for the cross-reactive idiotypes on the light chains of human IgM anti-IgG autoantibodies. Proc. Natl. Acad. Sci. USA. 83:8318-8322.

56. Moynihan, J. A., R. J. Looney, and G. N. Abraham. 1985. The $\mathrm{V}_{\mathbf{K}}$ IIIb light chain sub-subgroup: restricted association with mu heavy chain in normal serum. Immunology. 54:207-213.

57. Agnello, V., F. Goni, J. L. Barnes, M.-T. De La Vega, and B. Frangione. 1987. Human rheumatoid factor crossidiotypes. II. Primary structure-dependent crossreactive idiotype, PSL2-CRI, present on Wa monoclonal rheumatoid factors is present on Bla and other IgMk monoclonal autoantibodies. J. Exp. Med. 165:263-267.

58. Andrews, D. W., and J. D. Capra. 1981. Complete amino acid sequence of variable domains from two monoclonal human antigamma globulins of the Wa cross-idiotypic group: suggestion that the $J$ segments are involved in the structural correlate of the idiotype. Proc. Natl. Acad. Sci. USA. 78:3799-3803.

59. Stastny, P. 1978. Association of the B-cell alloantigen DRw4 with rheumatoid arthritis. N. Engl. J. Med. 298:869-871.

60. Nepom, G. T., J. A. Hansen, and B. S. Nepom. 1987. The molecular basis for HLA class II associations with rheumatoid arthritis. J. Clin. Immunol. 7:1-7.

61. Phillips, P. E., J. Waxman, Y. Hirshaut, and M. H. Kaplan. 1976. Virus antibody levels and delayed hypersensitivity in rheumatoid arthritis. Ann. Rheum. Dis. 35:152-154.

62. Norden, C. W., and L. H. Kuller. 1984. Identifying infectious etiologies of chronic disease. Rev. Infect. Dis. 6:200-213.

63. Procaccia, S., A. Lazzarin, A. Colucci, A. Gasparini, P. Forcellini, D. Lanzanova, C. Uberti Foppa, R. Novati, and C. Zanussi. 1987. IgM, IgG and IgA rheumatoid factors and circulating immune complexes in patients with AIDS and AIDS-related complex with serological abnormalities. Clin. Exp. Immunol. 67:236-244.

64. Diamond, B., and M. D. Scharff. 1984. Somatic mutation of the T15 heavy chain gives rise to an antibody with autoantibody specificity. Proc. Natl. Acad. Sci. USA. 81:5841-5844.

65. El-Roeiy, A., W. L. Gross, J. Ludemann, D. A. Isenberg, and Y. Shoenfeld. 1986. Preferential secretion of a common anti-DNA idiotype ( $16 / 6$ Id) and anti-polynucleotide antibodies by normal mononuclear cells following stimulation with Klebsiella pneumonia. Immunol. Lett. 12:313-319.

66. Sela, O., A. El-Roeiy, D. A. Isenberg, R. C. Kennedy, C. B. Colaco, J. Pinkhas, and Y. Shoenfeld. 1987. A common anti-DNA idiotype in sera of patients with active pulmonary tuberculosis. Arthritis Rheum. 30:50-56.

67. Naparstek, Y., D. Duggan, A. Schattner, M. P. Madaio, F. Goni, B. Frangione, E. D. Stollar, E. A. Kabat, and R. S. Schwartz 1985. Immunochemical similarities between monoclonal antibacterial Waldenstrom's macroglobulins and monoclonal anti-DNA lupus autoantibodies. J. Exp. Med. 161:1525-1538. 